\title{
透過式離岸堤構造物周辺の土砂移動解析手法の研究
}

\section{Study on Numerical Analysis for Sediment Transport around Permeable Detached Breakwaters}

\author{
西畑 剛 $^{1} \cdot$ 田島芳満 ${ }^{2} \cdot$ 佐藤愖司 ${ }^{3}$
}

Takeshi NISHIHATA, Yoshimitsu TAJIMA and Shinji SATO

\begin{abstract}
A numerical model was developed for sediment transport involving suspended load flux which was simultaneously solved with wave fields and current fields around permeable detached breakwaters. The validity of the model was verified through measurements of bathymetry changes in movable bed experiments with the structures conducted in a large wave basin. In the model, increase in friction velocity induced by plunging breaker was introduced which enhanced the erosion inside the surf zone. It is demonstrated that our model fairly reproduced the topography change due to partial standing waves on the offshore side of the structure, rip-current and longshore currents around the permeable detached breakwaters.
\end{abstract}

\section{1. はじめに}

我が国の侵食海岸において，対策工として透過型の有 脚式離岸堤の建設例が増えている。こうした離岸堤群は 旧建設省によるMMZ（Marine Multi Zone）計画以降に実 海域で多数施工されているが, 背後海域の静穏度確保な らびに海岸保全のため一定の消波性能を有することが規 定される。また環境への配慮から透過式構造となってい ること, 大水深への設置に対応して有脚式構造の採用例 が多いことが特徵である. 図-1に本研究で検討した透過 式離岸堤構造物の一つである S-VHS工法のイメージを示 す. 構造物周辺では反射波浪や透過波浪のほか, 構造物 内部での消波や越波に伴う砕波が発生する。こうした透 過式離岸堤周辺における波浪場, 海浜流場に対して, こ れまで筆者らは修正ブシネスク方程式に本離岸堤のよう な局所的に空隙率が異なる構造物を考慮可能とする数值 解析手法を研究してきた（西畑ら, 2010 ; 以下, 前報と 略す)。その結果，こうした構造物周辺における平面波 浪場, 海浜流場の解析手法の提案に至っている. 一方, 海岸保全の観点からは透過式離岸堤による土砂移動の把 握も重要であるが, 周辺で形成される複雑な波浪㧍よび 海浜流に伴う土砂移動を解析する手法は確立されてい ない.

本研究では, 上述の数值モデルに基づき解析された透 過式構造物周辺に打ける波浪場・海浜流場に浮遊砂フラ ックスによる土砂移動モデルを適用し, 波・流れ・地形 変化を一体的に解析する計算モデルを構築することを目 的とする. 計算モデルは平面 2 次元解析であるため, 3 次

$\begin{array}{llll}1 & \text { 正会員 } & \text { 博(工) } & \text { 五洋建設 (株), 技術研究所 } \\ 2 & \text { 正会貝 } & \text { Ph.D. } & \text { 東京大学准教授, 工学系研究科 } \\ & \text { 社会基盤学尃攻 } \\ 3 & \text { フェロー } & \text { 工博 } & \text { 東京大学教授, 同上 }\end{array}$

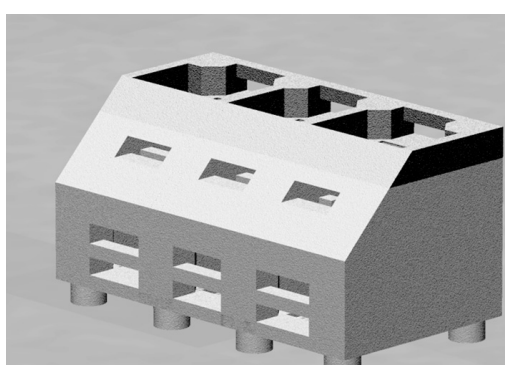

図-1 S-VHS工法イメージ

元構造が重要となる構造物下の局所洗掘を除く構造物前 面から背後海域にかけた広域に渡る土砂移動の再現を主 眼とし, 平面移動床実験によって把握された構造物周辺 における地形変化結果から解析の妥当性を検証した。

\section{2. 解析概要}

\section{（1）波浪場・海浜流場の解析手法}

透過式離岸堤構造物周辺における波浪場, 海浜流場の 数值解析は, 修正ブシネスク方程式に透水層による遡上 を考慮可能としたMadsenら（1997）に基づく解析手法を 基礎方程式として採用している. 透過式離岸堤への適用 に当たり, 構造物の局所的な空隙率を乱流抵抗と共に取 り込み, 水没.干出を繰り返す構造物天端は急拡損失項 を導入することで移流項を安定化させている．ここでは 次節で述べる地形変化解析と関連する式を中心に記す が，詳細は前報を参照されたい。

以下に本研究で用いる連続式, 運動方程式を記す.

$$
\begin{aligned}
& \alpha \frac{\partial \eta}{\partial t}+\frac{\partial P_{i}}{\partial x_{i}}=0 \\
& \frac{\partial P_{i}}{\partial t}+\frac{\partial}{\partial x_{j}}\left(\frac{P_{i} P_{j}}{A}\right)+g A \frac{\partial \eta}{\partial x_{i}}+\Psi_{i}+D_{f, i}+D_{b, i}=0
\end{aligned}
$$




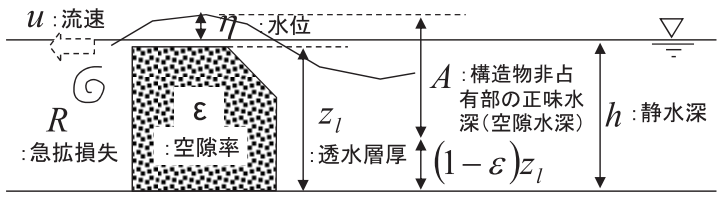

図-2 数值解析で用いる変数

ここで, $\eta:$ 水位, $P$ : 線流量, $\alpha: z=\eta$ で定義される空 隙率, $A=h+\eta-(1-\varepsilon) z_{1}$ : 空隙水深, $h$ : 静水深, $\varepsilon$ : 鉛直平均した空隙率, $z_{I}$ : 透水層厚, $g$ : 重力加速度, $\Psi$ : 分散項, $D_{f, i}=-f\left(z_{l} \varepsilon / A\right) u_{i}\left|u_{i}\right|$ : 摩擦項であり, 抵 抗係数 $f$ は実験等により設定される, $u$ : 流速, $D_{b}$ : 砕 波減衰項を示す。なお添字 $x_{i}$ は軸上 $(i=1,2)$ の座標を 意味し, 共通しない添字に対しては総和規約を適用する。 数值解析に用いる变数を図-2にまとめる.

前報では透過式離岸堤のほかswash zoneも微小な空隙 を有するポーラス構造を与えることで, 遡上を計算して いた，本研究では平山・平石（2004）と同様の越流公式 を用いて遡上を解析している.

砕波減衰項は, 田島ら（2006）が水平天端を有するブ ロック潜堤に適用した異方拡散型の挽波モデルを用いる ことで, 沿岸流の再現性を向上させている。ここで, 拡 散係数は平山・平石 (2004) と同様に砕波に伴う乱れ工 ネルギーの移流・拡散・生成・逸散式に基づき空間的に 平滑化した次式で与える.

$$
\begin{aligned}
& \frac{\partial k}{\partial t}+\frac{P_{i}}{A} \frac{\partial k}{\partial x_{i}}-\frac{\partial}{\partial x_{j}}\left(v_{T} \frac{\partial k}{\partial x_{j}}\right)=P_{*}-\frac{C_{D} k^{3 / 2}}{l_{t}} \cdots(3) \\
& v_{T}=\sqrt{k} l_{t}
\end{aligned}
$$

$k$ : 乱れエネルギー, $v_{T}$ : 拡散係数であり式 (4) で空間 分布が評価される. $P_{*}$ : 定常状態における乱れの生成項, $l_{t}=1.5 H_{0}, C_{D} \approx 0.09, H_{0}$ : 沖波波高である.

\section{(2) 地形変化の解析手法}

地形変化は掃流漂砂量と浮遊漂砂量を前節で述べた波 浪場, 海浜流場解析と一体的に評価する, 以下, 本研究 で用いた底質の連続式, 掃流漂砂量式, 浮遊漂砂量式, 摩擦速度について説明する。

\section{a) 底質の連続式}

地形変化は底質の掃流漂砂量フラックスと浮遊砂の巻 上げ, 沈降をバランスさせた以下の連続式から算定する.

$$
(1-n) \frac{\partial h}{\partial t}=-\frac{\partial q_{b, i}}{\partial x_{i}}-p+w_{f} C_{b}
$$

ここで, $h$ : 水深, $n$ : 砂の空隙率であり 0.4 とした. $q_{b}$ : 掃流漂砂量フラックス, $p$ : 砂の巻上げ率, $w_{f}$ : 砂の 沈降速度であり, Jimenez ・ Madsen（2003）の式を用い た. $C_{b}$ : 底面浮遊砂濃度である. 巻上げ率と底面浮遊砂 濃度の決め方は後述する。

\section{b）掃流漂砂量式}

掃流漂砂量は以下の Meyer-Peter-Muller式から決定した.

$$
q_{b, i}=8\left(\psi-\psi_{c}\right)^{1.5}=\frac{8}{(s-1) g \rho^{1.5}}\left(\tau_{b}-\tau_{b c}\right)^{1.5} \frac{\tau_{b, i}}{\tau_{b}}
$$

ここで, $\Psi$ : 無次元掃流力, $\Psi_{c}$ : 無次元限界掃流力であ るがSoulsby・Whitehouse（1997）に従って設定した。 $\tau_{b}$ : 底面せん断力, $\tau_{b c}$ : 限界底面せん断力, $s$ : 砂の比 重, $\rho$ : 水の密度, $g$ : 重力加速度である. 底面せん断力 の算定手法は後述する。

\section{c) 浮遊漂砂量}

鉛直平均した浮遊砂濃度は以下の移流拡散方程式より 求める.

$$
\frac{\partial C h}{\partial t}+\frac{\partial}{\partial x_{i}}\left(C P_{i}\right)=p-w_{f} C_{b}+\frac{\partial}{\partial x_{i}}\left(\varepsilon_{t} \frac{\partial C h}{\partial x_{i}}\right)
$$

$\varepsilon_{t}$ は拡散係数であり, $\varepsilon_{t} \kappa u_{*} h / 2$ で与えた. $u_{* b}$ : 底面摩擦 速度, $C$ : 鉛直平均した浮遊砂濃度であり, 濃度の鉛直 分布は, 次の鉛直方向の拡散方程式から求める.

$$
v_{s} \frac{\partial C(z)}{\partial z}+w_{f} C(z)=0
$$

渦動拡散係数 $v_{s}$ は鉛直方向へ線形増加する次式で与える.

$$
v_{s}=\kappa u_{* b} z
$$

$\kappa$ ：カルマン定数 $=0.4$ である. 定常状態を仮定すると式 （8）拉よび式（9）による解析解から $z=z_{b}$ における浮遊 砂濃度 $C_{b}$ は鉛直平均濃度から以下の通り逆算される。

$$
C_{b}=\frac{(1-m)\left(h-z_{b}\right)}{h\left(z_{b} / h\right)^{m}-z_{b}} C
$$

$m$ : ラウス数 $=w_{f} / \kappa u_{*_{b}}$ である. また巻上げ率 $p$ は, 底面 $z=z_{b} 7 d$ ( $d$ : 底質粒径) におけるHerrmann M Madsen （2007）の実験式を用いた.

$$
p=0.0022 w_{f}\left(\tau_{b} / \tau_{c}-1\right)
$$

\section{d）摩擦速度の評価}

底面せん断力, 摩擦速度は次式より求める.

$$
\tau_{b}=\rho u_{* b}^{2}=\frac{1}{2} \rho f_{w} u_{b}^{2}
$$

ここで摩擦係数 $f_{w}$ は一般に 0.01 から 0.02 とされるが, 本 研究では 0.015 とした。波浪場・海浜流場の解析時間又 テップ毎の断面平均速度から底面摩擦速度を算定する.

$$
u_{* b, i}=\sqrt{\frac{f_{w}}{2}} \frac{k h}{\sinh (k h)} U_{i}
$$


$k$ : 波数, $U_{i}$ : 断面平均流速であり, 式（2）より求まる. 砕波が発生する領域では, 砕波水塊による乱れの増大 によって浮遊砂がより多く巻き上がる. そこで本研究では 高波浪時における砕波に伴う浮遊砂巻上げ量の増大の評価 を試みる，すなわち，砕波による摩擦速度増分を評価する.

いま砕波帯内で進行波型の長波近似が成立すると仮定 すれば，(4）式で空間分布形が決まる拡散型砕波係数と 波エネルギーの減衰率には以下の関係が成立する.

$$
D=k^{2} v_{T} E \approx \frac{\omega^{2}}{g h} v_{T} \cdot \frac{1}{8} \rho g H_{b}{ }^{2}
$$

ここで, $D$ ：単位重量当たりの波エネルギー減衰率平 均, $E$ : 波エネルギー平均, $\rho$ : 流体密度, $\omega$ : 角周波数, $H_{b}:$ 砕波波高である.

一方，田島・Madsen（2005）は，Surface Rollerによる 砕波を想定し，砕波波谷における摩擦速度増分を次式で 算定している.

$$
u_{*_{s B}}=\kappa\left(\frac{D}{2 \rho}\right)^{1 / 3}
$$

式（14），(15）より波谷における砕波による摩擦速度 増分を次式で与え, 砕波帯内で（9）式の渦動拡散係数 および（10）式のラウス数を割り増した.

$$
u_{*_{s B}}=\kappa\left(\frac{\omega^{2} v_{T} H_{b}{ }^{2}}{16 h}\right)^{1 / 3}
$$

さらに底面における巻上げについては，鉛直方向に線 形に増大する渦動粘性係数を仮定して砕波による増分を 評価する。すなわち，

$$
\begin{gathered}
\tau(z)=\rho v_{t} \frac{\partial u}{\partial z} \\
v_{t}=\kappa u_{*_{b}} z
\end{gathered}
$$

というせん断力形を与え, 微小振幅波による流速分布か ら砕波波谷と底面におけるせん断力の比を次式で表す.

\begin{tabular}{|c|c|c|c|c|c|c|}
\hline case & 模型 & 波浪 & $\begin{array}{l}\text { 波高 } \\
(\mathrm{cm})\end{array}$ & $\begin{array}{l}\text { 周期 (s) } \\
\text { 波向 }\left({ }^{\circ}\right)\end{array}$ & $\begin{array}{c}\text { 造波時間 } \\
\text { (分) }\end{array}$ & $\begin{array}{c}\text { 砂面計測 } \\
\text { (分) }\end{array}$ \\
\hline 1 & 無 & \multirow{2}{*}{ 常時 } & \multirow{2}{*}{5} & \multirow{4}{*}{$\begin{array}{l}1.5 \\
20\end{array}$} & \multirow{2}{*}{150} & 75 \\
\hline 2 & 有 & & & & & 150 \\
\hline 3 & 無 & \multirow{2}{*}{ 高波浪 } & \multirow{2}{*}{12} & & \multirow{2}{*}{60} & 30 \\
\hline 4 & 有 & & & & & 60 \\
\hline
\end{tabular}

$$
K_{b s} \equiv \frac{\tau_{b}}{\tau_{s}}=\frac{f_{w}}{2}[\kappa k h \sinh (k h)]^{-2}
$$

砕波波谷における摩擦速度増分に上式の比率を乗じ，巻

$$
\text { 表-1 平面模型実験検討ケース }
$$

上げ率に関する式（11）中の底面せん断力を割り増す.

\section{3. 平面移動床実験と再現解析}

\section{(1) 平面移動床実験概要}

透過式離岸堤周辺の土砂移動解析に際し，西畑・佐藤 （2010）による平面移動床実験を検証に用いる。実験ケ ースを表-1に，実験平面および断面を図-3に示す。実験 は，単一方向規則波にて，常時波浪および高波浪を想定 した波浪条件にて実施した。透過式離岸堤模型を設置し た場合と比較のため模型を設置しない場合の4ケースを 行い, 沿岸漂砂の発生が見达まれるように波向きは造波 位置で $20^{\circ}$ つけた。模型縮尺は $1 / 50$, 実験平面は造波板 で反射波を吸収制御，側面には導波板を設置して完全反 射境界とした。模型は開口部を設けて 3 基設置した。床 面の一部は $10 \mathrm{~cm}$ 下げ，6号硅砂（中央粒径 $0.16 \mathrm{~mm}$ ）を 敷設して移動床とした. ケース 1 ，2では漂砂の下手側に サンドトラップも設置し, 沿岸漂砂を計測している。ま た計測台車に光電式砂面計を設置することで，造波前後 の地形変化を捉えた（計測は $5 \mathrm{~cm}$ 間隔, 模型周辺は $2.5 \mathrm{~cm}$ 間隔). なお模型は基礎杭から着脱可能であるため, 模型下の洗掘も計測している. 波浪場, 海浜流場は今回 計測をしていないが，前報にて固定床実験による計測を


図-3 実験平面図（上）および断面図（下）

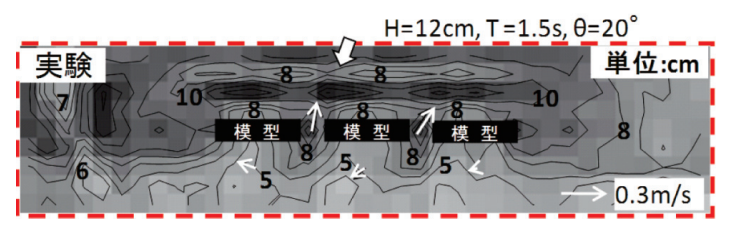

図-4 実験波高・流速分布（ケース4，前報固定床実験結果） 

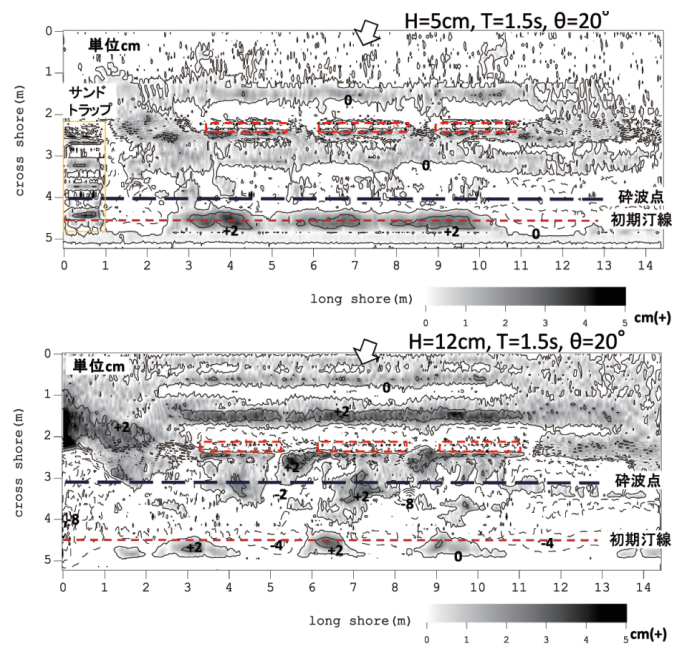

図-5 実験侵食堆積分布

(上：ケース2（75分後), 下：ケース4 (30分後))
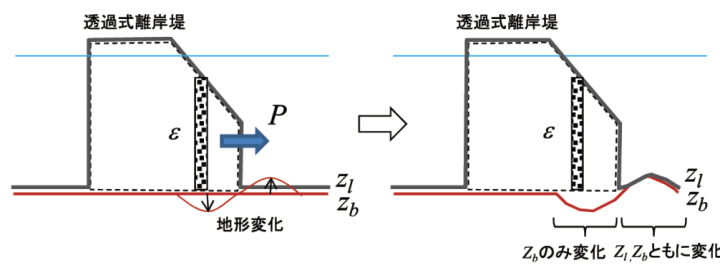

図-6 構造物直下における地形変化の扱い方

行っており，模型設置時には前面で重複波浪場，背後砕 波帯内で右から左への沿岸流が計測された。参考までに 前報・固定床実験でケース 4 に相当する模型周辺の波浪 場・海浜流場を図-4に示す。本実験条件を Sunamura ・ Horikawa（1974）の基準に照合すると常時で中間型，高 波浪時で侵食型の岸沖漂砂が想定される．実際，模型を 設置しないケース1では，汀線付近や砕波点付近のステ ップで堆積, 他で侵食, ケース3では全体的に侵食傾向 となった，透過式離岸堤を設置すると，構造物背後で漂 砂は捕捉される傾向となる（図-5)。すなわち常時波浪に


における土砂堆積が見られ，サンドトラップに捕捉され る沿岸漂砂は減少する。一方，ケース4でも汀線際で舌 状砂州の発達や構造物背後での土砂捕捉は見られるもの の全体的には依然，侵食傾向である。開口部では離岸流 に伴う沖向き漂砂があり, 開口部背後の砕波点付近は巻 波研波によって大きく侵食, 模型下は洗掘した.

\section{(2) 平面移動床実験への数值解析の適用}

平面移動床実験の再現解析は図-3に示した地形のうち サンドトラップを砂で置き換えた解析地形で実施した. 解析は空間格子 $2 \mathrm{~cm}$, 時間格子は波浪場・海浜流場解析 で $0.001 \mathrm{~s} ，$ 漂砂解析で $0.005 \mathrm{~s}$ とし，ケース 2 の 75 分後お
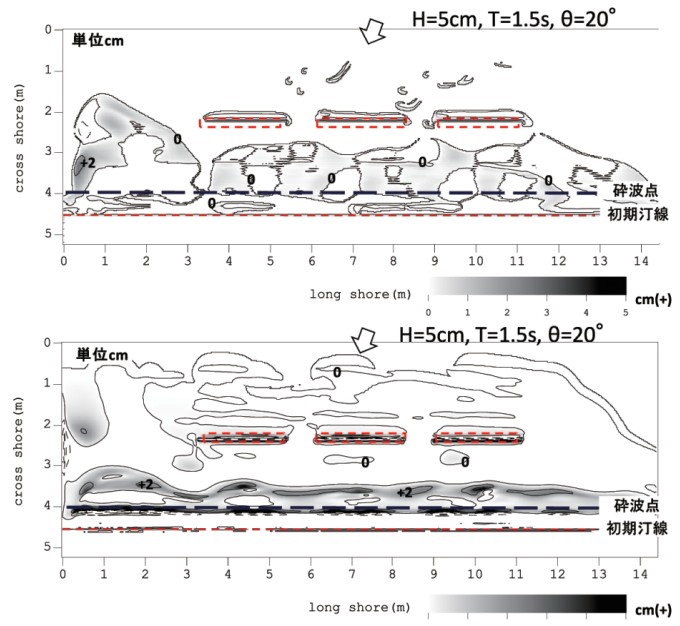

図-7 解析侵食堆積分布

（ケース 2, 上：局所漂砂量モデル，下：浮遊砂フラックスモデル）
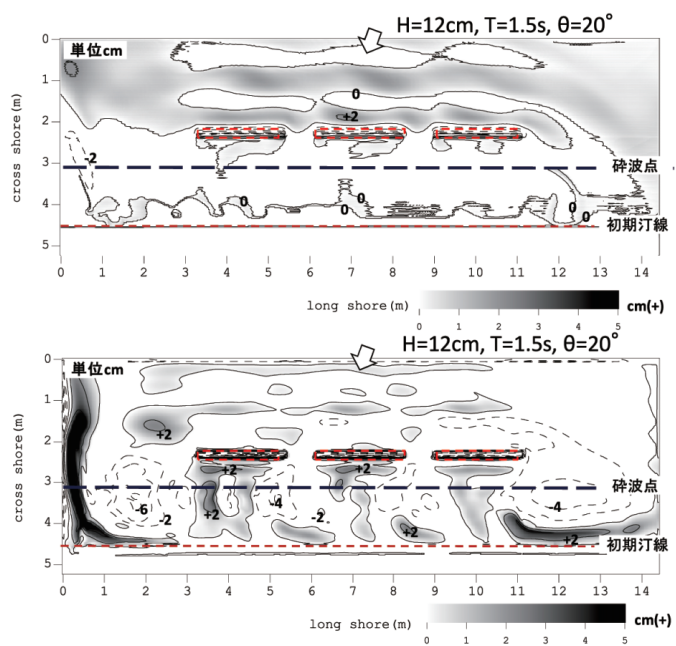

図-8 解析侵食堆積分布

(ケース 4, 上: 局所漂砂量モデル，下：浮遊砂フラックスモデル)

よびケース 4 の 30 分後を検討した．模型部は鉛直断面平 均した空隙率を考慮しつつ式（2）に基づく抵抗係数を 与えた。なお模型下では洗掘が発生するが，これは本来， 3 次元の流体㧍よび模型構造を考慮する必要があり，平 面2次元解析に基づく本研究の支配方程式では再現し得 ない現象である。ここでは離岸堤上端レベルと地盤レベ ルを分けて考え，構造物下部では見かけ上解析される断 面平均流速に応じた地形変化量を地盤レベルにのみ与え て，空隙率を変化させた（図-6)。また汀線付近では，越 流公式に基づく遡上解析を行ったが，遡上域では引き波 による沖向き漂砂と砕波ボアによる岸向き漂砂がバラン スすると考えられるが，後者は再現しえない，そこで佐 藤・Kabiling（1993）と同様に数值解析上は一定の水深 




図-9 解析侵食堆積分布 (浮遊砂フラックスモデル, 割増し無)

から遡上先端までは，一定水深位置における漂砂量を線 形内捙した。一定水深は沖波波高の1 割とした.

なお, 解析は本研究の浮遊砂フラックスモデルとの比 較のため，渡辺（1981）に基づく局所漂砂量モデルでも 解析した。修正ブシネスク方程式による波浪場と海浜流 場の解析結果を別途読み込むことで計算を実施した．図7にケース 2 における解析侵食堆積分布を比較する。離岸 堤背後の堆積傾向は両モデルとも再現されている。一方 で離岸堤前面の重複波浪場形成に伴う侵食堆積分布は弱 いながら浮遊砂フラックスモデルでのみ形成される。な お汀線から遡上域にかけての砂州形成の解析精度は悪 い.これは前述したように一定水深から遡上域まで線形 内捙した影響と考えられ，今後の課題である. 図-8にケ 一ス 4 の解析侵食堆積分布を比較する。全体的な侵食傾 向は両モデルに共通する.しかし離岸堤前面の重複波浪 場における侵食堆積分布は, 局所漂砂量モデルでは分布 が反転しているが，波・流れ・漂砂を一体的に解析した 浮遊砂フラックスモデルでは位相も考慮され整合する. また砕波による浮遊砂巻き上げ量の増加を考慮したた め, 離岸堤開口部背後の侵食も再現されている.この増 分を考慮しない場合の解析を図-9に示すが, 砕波点にお ける顕著な侵食傾向や舌状砂州は再現されない. 最後に ケース4に扔ける解析海浜流と浮遊砂濃度分布（解析開 始 1 分後）を図-10に示す. 砕波帯内では右から左へ沿岸 流が解析され, 開口部背後砕波点付近では浮遊砂の巻上 げ量も多く, 開口部では沖への離岸流と沖向き漂砂が解 析される，高波浪時にはこうした浮遊形態での漂砂が多 く, 浮遊砂フラックスモデルによる解析が有効と言える.

\section{4. おわりに}

透過式離岸堤構造物周辺の土砂移動を解析するため浮 遊砂フラックスモデルによる解析手法を構築し, 水理実 験による検証を行った，以下に結論をまとめる.

（1）物理メカニズムに基づく浮遊砂フラックスモデルを 用いた数值解析によって, 透過式離岸堤による部分重 複波浪場や挽波帯から開口部にかけての浮遊砂の移流



図-10 解析海浜流・浮遊砂濃度（ケース4)

による地形変化の再現精度が向上する。

(2) 砕波モデルに組み込んだ乱れエネルギーの移流・拡 散式から算定される砕波係数と砕波波高から波のエネ ルギー減衰率を評価した。これを用いて巻波砕波に伴 う摩擦増分を評価することで, 砕波点付近の侵食解析 精度が向上する。

\section{参 考 文 献}

佐藤懭司・M., Kabiling（1993）：Boussinesq方程式を用いた波 浪・海浜流 - 海浜変形の数值計算, 海工論文集, 第 40 巻, pp. 386-390.

田島芳満・O. S. Madsen（2005）：Surface Rollerによる影響を 考慮した戻り流れの鉛直分布のモデリング，土木学会論 文集, No.803/II-73, pp. 133-144.

田島芳満 - 佐藤愼司 - 鈴木淳也 - 下園武範 · 磯部雅彦 （2006）：潜堤周辺の砕波・乱流特性を考慮した海浜流場 予測モデルに関する一考察, 海工論文集, 第 53 巻, pp. 106-110.

西畑 剛 ・佐藤㥀司 (2010) : 有脚式離岸堤構造物による漂砂 制御機能に関する実験的研究, 海洋開発論文集, 第 26 巻, pp. 1143-1148.

西畑 剛 - 田島芳満 - 佐藤愼司 (2010)：低天端透過式離岸堤 周辺の波浪場・海浜流場の解析手法の研究, 海工論文集, 第 57 巻, pp. 701-705.

平山克也・平石哲也（2004）：ブシネスクモデルによる砕波・ 遡上計算法とその適用性, 海工論文集, 第 51巻, pp. 11-15.

渡辺 晃 (1981) : 海浜流と海浜変形シミュレーション, 海工 論文集, 第28巻, pp. 285-289.

Herrmann, M. and O. S. Madsen (2007) : Effect of stratification due to suspended sediment on velocity and concentration distribution in unidirectional flows, J. Geophys. Res., Vol.112, p. 13.

Jimenez, J. A. and O. S. Madsen (2003) : A simple formula to estimate settling velocity of natural sediments, Journal of Waterway, port, Coastal and Ocean Engineering, ASCE, 129 (2), pp. 70-78.

Madsen, P. A., O. R. Sorensen and H. A. Schaffer (1997) : Surf zone dynamics simulated by a Boussinesq type model. Part 1 . Model description and cross-shore motion of regular waves, Coastal Engineering, ASCE, pp. 255-287.

Soulsby, R. L. and R. J. S. W. Whitehouse (1997) : Threshold of sediment motion in coastal environments. Proc. Pacific Coasts and Ports Conf., 1, pp. 149-154.

Sunamura, T. and K. Horikawa (1974) : Two dimensional shore transformation due to waves. Proc. 14th Coastal Eng., ASCE, pp. $920-930$. 